\title{
Susceptibility to deltamethrin of wild and domestic populations of Triatoma infestans of the Gran Chaco and the Inter-Andean Valleys of Bolivia
}

Marinely Bustamante Gomez ${ }^{1}$, Grasielle Caldas Pessoa D’Avila'', Ana Lineth Garcia Orellana², Mirko Rojas Cortez³,

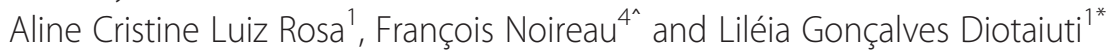

\begin{abstract}
Background: The persistence of Triatoma infestans and the continuous transmission of Trypanosoma cruzi in the Inter-Andean Valleys and in the Gran Chaco of Bolivia are of great significance. Coincidentally, it is in these regions the reach of the vector control strategies is limited, and reports of $T$. infestans resistance to insecticides, including in wild populations, have been issued. This study aims to characterize the susceptibility to deltamethrin of wild and domestic populations of $T$. infestans from Bolivia, in order to better understand the extent of this relevant problem.

Methods: Susceptibility to deltamethrin was assessed in nine, wild and domestic, populations of $T$. infestans from the Gran Chaco and the Inter-Andean Valleys of Bolivia. Serial dilutions of deltamethrin in acetone $(0.2 \mu \mathrm{L})$ were topically applied in first instar nymphs (F1, five days old, fasting, weight $1.2 \pm 0.2 \mathrm{mg}$ ). Dose response results were analyzed with PROBIT version 2, determining the lethal doses, slope and resistance ratios (RR). Qualitative tests were also performed.

Results: Three wild T. infestans dark morph samples of Chaco from the Santa Cruz Department were susceptible to deltamethrin with $\mathrm{RR}_{50}$ of $<2$, and $100 \%$ mortality to the diagnostic dose (DD); however, two domestic populations from the same region were less susceptible than the susceptibility reference lineage $\left(R_{50}\right.$ of 4.21 and 5.04 respectively and 93\% DD). The domestic population of Villa Montes from the Chaco of the Tarija Department presented high levels of resistance ( $\mathrm{RR}_{50}$ of 129.12 and $0 \% \mathrm{DD}$ ). Moreover, the domestic populations from the Valleys of the Cochabamba Department presented resistance (RR $\mathrm{R}_{50}$ of 8.49 and $\left.62 \% \mathrm{DD}\right)$, the wild populations were less susceptible than SRL and T. infestans dark morph populations $\left(\mathrm{RR}_{50}<5\right)$.

Conclusion: The elimination of T. infestans with pyrethroid insecticides in Brazil, Uruguay, Chile, and its drastic reduction in large parts of Paraguay and Argentina, clearly indicates that pyrethroid resistance was very uncommon in non-Andean regions. The pyrethroid susceptibility of non-Andean T. infestans dark morph population, and the resistance towards it, of Andean T. infestans wild and domestic populations, indicates that the Andean populations from Bolivia are less susceptible.
\end{abstract}

Keywords: Triatoma infestans, Control, Bolivia, Insecticide resistance, Deltamethrin

\footnotetext{
* Correspondence: diotaiut@cpqrr.fiocruz.br

'Deceased

'Laboratório de Triatomíneos e Epidemiologia da Doença de Chagas, Centro de Pesquisas René Rachou - FIOCRUZ Minas, Belo Horizonte, Brazil Full list of author information is available at the end of the article
} 


\section{Background}

Triatoma infestans (Hemiptera, Reduviidae) is the main vector of Trypanosoma cruzi (Trypanosomatidae), pathogenic agent of Chagas disease in the countries of the Southern Cone of Latin America [1,2]. Traditionally, the vector control programs focus on the interruption of transmission cycles using insecticides with residual action, especially pyrethroids [2]. Triatominae control strategies were originally based on ecoepidemiological characteristics of the group, such as their slow reproduction and vulnerability to chemical control, and aimed to eliminate T. infestans, despite the fact that this species has restricted wild foci [3]. Thereby in the last decades, Uruguay, Chile and Brazil were certified as free of transmission of T. cruzi by $T$. infestans $[4,5]$.

However, in the Gran Chaco in Argentina, Bolivia and Paraguay and in some areas of the Inter-Andean Valleys of Bolivia, despite the constant efforts to control T. infestans the success of these actions was limited and thus the species still persists [6,7]. In addition to this important problem, in the last few years, wild foci of $T$. infestans have been described, mainly in the Inter-Andean Valleys and in the Gran Chaco [8,9]. This fact was also observed in Argentina, Paraguay and Chile, showing that wild T. infestans have dispersed more widely than expected [10-14]. In Bolivia, the epidemiological significance of wild foci of $T$. infestans has been stressed [10].

The process of reinfestation of houses treated with insecticides is a serious phenomenon, and it is occurring quickly in the Gran Chaco [6,15-17]. It is considered that vector control failures, are due to high levels of insecticide resistance in this area [18-21]. In the last few years, more studies demonstrated that the phenomenon of resistance to insecticides in domestic T. infestans populations presents an extensive distribution in southern Bolivia and northern Argentina [21-23], with high resistance ratios, and different toxicological profiles [14,18,19,24-26]. Recently, susceptibility and resistance to deltamethrin and fipronil were detected in wild populations of $T$. infestans from Bolivia [14,27].

Coincidence or not, it is in those regions that the reach of the vector control strategies is limited, and insecticide resistance in $T$. infestans populations has been reported, including wild populations [14,27-29]. Thus, this study proposes to characterize the susceptibility to deltamethrin of wild and domestic T. infestans from the Gran Chaco and Inter-Andean Valleys in Bolivia, in order to understand better the extent of this relevant problem.

\section{Methods}

Populations of $T$. infestans

Nine populations of $T$. infestans five wild (S) and four domestic (D) were collected in the period from 2010 to
2011, in the region of Gran Chaco and Inter-Andean Valleys in Bolivia.

Wild T. infestans were captured using traps described by Noireau et al. [30,31]. In the Gran Chaco, they were captured in hollow tree trunks, whereas in the InterAndean Valleys in rock outcrops.

The collection of the domestic $T$. infestans, both in the Inter-Andean Valleys and in the Gran Chaco, was performed through active searches in intradomicile and peridomicile, with assistance of technicians from the National Chagas Disease Control Program of Bolivia (NCHDCP) (Table 1).

All insects collected were identified using the taxonomic key of Lent and Wygodzinsky [35] and maintained under controlled conditions of temperature and humidity $\left(25^{\circ} \mathrm{C}\right.$ $\left.\pm 1^{\circ} \mathrm{C} ; 60 \% \pm 10 \% \mathrm{RH}\right)$. They were fed weekly with chicken blood (Gallus gallus), ethical approval Comissão de Ética no Uso de Animais (PROTOCOL N ${ }^{\circ}$ 41/14-2).

\section{Insecticide}

Deltamethrin (pyrethroid) technical grade $(S)$ - cyano-3pehoxybenzyl (1R) -cis-3- (2,2-dibromovinyl) -2,2-dimethylcyclopropane Carboxylate, (99.6\% - Bayer ${ }^{\circledR}$, Brazil) was used.

\section{Bioassays}

The susceptibility reference lineage (SRL) of T. infestans came from Centro de Investigaciones de Plagas e Insecticidas (CIPEIN) [36], preserved in the laboratory for more than 30 years, without contact with insecticide and inclusion of external material was used.

Serial dilutions of deltamethrin in acetone were prepared. For each concentration, three repetitions were carried out with ten first instar nymphs of F1 generation (five days old, fasting, weight of $1.2 \pm 0.2 \mathrm{mg}$ ). The treatment consisted of the application of $0.2 \mu \mathrm{L}$ of insecticide dilution on the dorsal abdomen, according to the World Health OrganizationWHO [37] and Pessoa [38] procedures, with the aid of a Hamilton micro-syringe mounted on a repeating dispenser. For each population, a minimum of eight doses of insecticide active ingredient (a.i.) ranging from 0.42 to $300 \mathrm{ng}$ and killing between $>0 \%$ to $<100 \%$ of the individuals, were applied per insect. Acetone was applied to the control group. The mortality was assessed 72 hours after application and it was determined by the inability or lack of coordination of the nymphs to move from the center to the edge of the filter paper (7 $\mathrm{cm}$ diameter). Signs of paralysis and lack of response to external stimuli was considered as well. During and after the experiment, the insects were kept under controlled conditions of temperature and humidity $\left(25^{\circ} \mathrm{C} \pm 1^{\circ} \mathrm{C}\right.$; $60 \% \pm 10 \% \mathrm{RH})$.

\section{Diagnostic dose}

The diagnostic dose (DD) applied was twice the minimum concentration of the insecticide that causes $99 \%$ of 
Table 1 Samples of wild (S) and domestic (D) populations of Triatoma infestans, geographical origin, capture site (ecotope), morphs and cytogenetic classification

\begin{tabular}{|c|c|c|c|c|c|c|}
\hline Site of collection & Department/Province & Latitude/longitude & Altitude meters & Capture site Ecotope & Morphs $^{a}$ & Cytotype $^{b}$ \\
\hline CIPEIN [SRL] & Susceptible reference strain & - & - & - & - & - \\
\hline San Silvestre - S & $\begin{array}{l}\text { Santa Cruz de la } \\
\text { Sierra/Cordillera }\end{array}$ & $19^{\circ} 21^{\prime} 21^{\prime \prime} \mathrm{S} / 62^{\circ} 34^{\prime} 10^{\prime \prime} \mathrm{W}$ & 400 & Tree trunk & Dark morph & Non-andean \\
\hline Terra Plem -S & $\begin{array}{l}\text { Santa Cruz de la } \\
\text { Sierra/Cordillera }\end{array}$ & $19^{\circ} 09^{\prime} 27^{\prime \prime} \mathrm{S} / 62^{\circ} 38^{\prime} 8^{\prime \prime} \mathrm{W}$ & 400 & Tree trunk & Dark morph & Non-andean \\
\hline Tita Chaco - S & $\begin{array}{l}\text { Santa Cruz de la } \\
\text { Sierra/Cordillera }\end{array}$ & $18^{\circ} 55^{\prime} 39^{\prime \prime} \mathrm{S} / 62^{\circ} 34^{\prime} 28^{\prime \prime} \mathrm{W}$ & 400 & Tree trunk & Dark morph & Non-andean \\
\hline Mataral - S & Cochabamba/Aiquile & $18^{\circ} 36^{\prime} 06^{\prime \prime} \mathrm{S} / 65^{\circ} 07^{\prime} 20^{\prime \prime} \mathrm{W}$ & 1,700 & Rock outcrop & Mataral morph & Andean \\
\hline Cotapachi - S & Cochabamba/Quillacollo & $17^{\circ} 25^{\prime} 29^{\prime \prime} \mathrm{S} / 66^{\circ} 15^{\prime} 56^{\prime \prime} \mathrm{W}$ & 2,556 & Rock outcrop & Common morph & Andean \\
\hline Mataral - D & Cochabamba/Aiquile & $18^{\circ} 35^{\prime} 44^{\prime \prime} \mathrm{S} / 65^{\circ} 08^{\prime} 58^{\prime \prime} \mathrm{W}$ & 1,750 & $\begin{array}{l}\text { Domestic (intra } \\
\text { and peridomicile) }\end{array}$ & Common morph & Andean \\
\hline Tamachindi - D & $\begin{array}{l}\text { Santa Cruz de la } \\
\text { Sierra/Cordillera }\end{array}$ & $19^{\circ} 28^{\prime} 41^{\prime \prime S} / 19^{\circ} 28^{\prime} 41^{\prime \prime} \mathrm{W}$ & 410 & $\begin{array}{l}\text { Domestic (intra } \\
\text { and peridomicile) }\end{array}$ & Common morph & Non-andean \\
\hline Rancho Nuevo -D & $\begin{array}{l}\text { Santa Cruz de la } \\
\text { Sierra/Cordillera }\end{array}$ & $19^{\circ} 26^{\prime} 22^{\prime \prime} \mathrm{S} / 62^{\circ} 34^{\prime} 05^{\prime \prime} \mathrm{W}$ & 410 & $\begin{array}{l}\text { Domestic (intra } \\
\text { and peridomicile) }\end{array}$ & Common morph & Non-andean \\
\hline Villa Montes - D & Tarija/Gran Chaco & $21^{\circ} 09^{\prime} 02^{\prime \prime} \mathrm{S} / 63^{\circ} 21^{\prime} 56^{\prime \prime} \mathrm{W}$ & 463 & Domestic (peridomicile) & Common morph & Intermediate \\
\hline
\end{tabular}

${ }^{a}$ Morphs classification according to Noireau et al. [32], Cortez et al. [33].

${ }^{\mathrm{b}}$ Cytotypes classification according to Panzera et al. [34].

mortality in the susceptible laboratory strain [21,39]. According to the World Health Organization [39], when mortality is $<80 \%$ the tested population is considered resistant, and if $>98 \%$ it is considered as susceptible. The $\mathrm{LD}_{99}$ to deltamethrin of the SRL was determined (5.50 ng (a.i.) per insect) and with it the DD was estimated.

\section{Data analysis}

Data from dose - response tests from each population were analyzed using the PROBIT program version 2 [40]. The slope and the lethal doses required to kill 50\% of treated individuals $\left(\mathrm{LD}_{50}\right)$ were estimated, as well as the Resistance Ratio $\left(\mathrm{RR}_{50}\right)$, which was calculated by dividing each field population $\mathrm{LD}_{50}$ by the $\mathrm{SRL} \mathrm{LD}_{50}$ value.

\section{Results}

\section{Wild populations}

From the five wild populations studied, the ones collected at the San Silvestre, Terra Plem and Tita Chaco communities (Chaco region) were identified as T. infestans dark morph. These populations had a $R_{50}$ lower or equal to the SRL, and 100\% mortality to DD (Table 2). In agreement with PAHO criteria, they were considered as susceptible to deltamethrin since all had a RR $<5$.

Regarding the populations from the Inter-Andean Valleys, $T$. infestans from the Cotapachi community were identified as common morph and presented a $R_{50}$ of 2.90 and $100 \%$ mortality to the DD. Furthermore, Mataral community $T$. infestans individuals were identified as Mataral morph and presented a $\mathrm{RR}_{50}$ of 4.24 and $96 \%$ mortality to the DD (Table 2).
Interestingly, we observed that $T$. infestans dark morph from the Chaco had lower slopes than the SRL $(<2.83)$, whereas Mataral and Cotapachi populations had higher slopes (4.36 and 4.69, respectively).

\section{Domestic populations}

Out of the four domestic populations studied, all bugs were identified as $T$. infestans common morph. Domestic populations from Mataral had a $R_{50}$ of 8.49 and $62 \%$ mortality to the DD. In the Rancho Nuevo and Tamachindi populations the $\mathrm{RR}_{50}$ was 4.21 and 5.04 respectively with $93 \%$ mortality to the DD for both communities. The level of resistance estimated for the Villa Montes population $\left(\mathrm{RR}_{50}=129.12\right)$ and the mortality $\%$ to the $\mathrm{DD}(0 \%)$ drew our attention (Table 2).

Regarding the estimated slopes, the Tamachindi and Rancho Nuevo populations presented higher values than the SRL (5.46 and 4.43 respectively). On the other hand, resistant individuals from Mataral and Villa Montes presented slopes similar to the SRL (2.92 and 2.25 respectively).

\section{Discussion}

This study shows the high susceptibility to deltamethrin determined for three wild populations of $T$. infestans dark morph from the Gran Chaco region of Bolivia, which in turn corresponds to the non-Andean region according to the cytogenetic classification of Panzera et al. [34]. These populations presented $R_{50}$ values equal to or less than the SRL. According to the criteria established by PAHO [41] they were considered susceptible to the tested insecticide $\left(\mathrm{RR}_{50}<5\right)$. Notwithstanding, wild Andean populations 
Table 2 Toxicological profile to deltamethrin in wild and domestic Triatoma infestans from Gran Chaco and the Inter-Andean Valleys of Bolivia

\begin{tabular}{|c|c|c|c|c|c|c|}
\hline Population & $\mathbf{N}^{\circ}$ & Slope +/- SD & $X^{2}(d f) P$ & $\mathrm{LD}_{50}(95 \% \mathrm{Cl})$ & $\mathrm{RR}_{50}(95 \%)$ & $\mathrm{DD} \%\left(\mathrm{~N}^{\circ}\right)$ \\
\hline CIPEIN (SRL) & 240 & $2.83+/-0.04$ & 3.43 (4) 0.51 & $0.42(0.35-0.49)$ & - & - \\
\hline San Silvestre - S & 300 & $1.97+/-0.05$ & $0.51(6) 0.00$ & $0.26(0.21-0.32)$ & 0.62 & $100(60)$ \\
\hline Terra Plem - S & 300 & $2.61+/-0.03$ & $2.72(6) 0.15$ & $0.39(0.33-0.46)$ & 0.93 & $100(60)$ \\
\hline Tita Chaco - S & 270 & $2.72+/-0.04$ & $0.54(5) 0.01$ & $0.48(0.41-0.58)$ & 1.16 & $100(60)$ \\
\hline Mataral - S & 390 & $4.36+/-0.02$ & 1.75 (9) 5.16 & $1.78(1.63-1.93)$ & 4.24 & $96(60)$ \\
\hline Cotapachi - S & 240 & $4.69+/-0.02$ & $1.72(6) 0.05$ & $1.22(1.11-1.34)$ & 2.90 & $100(66)$ \\
\hline Tamachindi - D & 390 & $5.46+/-0.02$ & $1.43(9) 2.35$ & $1.75(1.62-1.87)$ & 4.21 & $93(60)$ \\
\hline Rancho Nuevo -D & 390 & $4.43+/-0.02$ & $2.41(10) 7.94$ & $2.09(1.93-2.27)$ & 5.04 & $93(45)$ \\
\hline Mataral - D & 480 & $2.92+/-0.30$ & 1.84 (2) 0.00 & $3.52(3.15-4.02)$ & 8.49 & $62(60)$ \\
\hline Villa Montes - D & 360 & $2.25+/-0.04$ & 3.05 (9) 0.04 & $54.23(45.54-63.32)$ & 129.12 & $0(50)$ \\
\hline
\end{tabular}

SD: standard deviation; $\mathrm{X}^{2}$ : chi-squared; $d f$ : degrees of freedom; P: probability value; $\mathrm{LD}_{50}$ : Insecticide dose that killed $50 \%$ of the population (ng/insect); Cl: confidence intervals; RR: resistance ratio; DD: \% mortality of the discriminating dose; SRL: susceptible reference lineage; S: Sylvatic (wild); D: Domestic; $N^{\circ}$ : number of individuals used.

from Mataral and Cotapachi were less susceptible than SRL and T. infestans dark morph populations.

Interestingly, wild $T$. infestans Mataral morph had a $\mathrm{RR}_{50}=4.24$ and thus they are less susceptible than the SRL, but less thanRR $R_{50}=5$ (PAHO criteria) and thus would be considered as susceptible. However, previous studies performed by Roca-Acevedo et al. [27] on the same region had reported individuals resistant to deltamethrin and fipronil $\left(R_{50}=11.9\right.$ e 23.4 respectively). Additionally, in our study of domestic T. infestans in the same area we observed a deltamethrin $R R_{50}$ of 8.49 whereas Roca-Acevedo et al. [27] reported a $R_{50}$ of 17.4. The differences between the values may be due to the fact that Roca-Acevedo et al. [27] used a different SRL to estimate the $R_{50}$.

Depickère et al. [14] reported $96 \%$ mortality to the deltamethrin DD in individuals from a wild Mataral population. Our results for individuals from the same population agree with this report. The same authors reported the susceptibility of eight wild populations of T. infestans, corresponding to the Andean region [34] from Bolivia. Among the populations they tested, the one from Cotapachi, presented a $100 \%$ mortality to the DD. Our study also evaluated a wild population from the same region, and similar qualitative test results were obtained (100\% mortality to the DD). Nevertheless, the individuals we tested were less susceptible to deltamethirn than the SRL $\left(\mathrm{RR}_{50}=2.90\right)$.

The DD is a qualitative method for rapid detection of resistant populations. Several T. infestans insecticide resistance studies have evaluated toxicological profiles using RR and DD criteria [14,18-21,27]. Nevertheless, the results obtained by both criteria are not always congruent. Thus, Picollo [42] proposed that the single dose killing $99 \%$ of the SRL (1X $\mathrm{LD}_{99}$ ) would be a more appropriate DD value. This dose permits detecting high mortality among susceptible individuals and low mortality among resistant. Increasing the DD value to twice the $\mathrm{LD}_{99}$, as proposed by Lardeux et al. [21], carries the risk of identifying resistant individuals as susceptible due to the high mortality \% that would be estimated. This could occur mainly in populations that are in the process of selection for the resistance character, populations in which the toxicological profile would be masked. In contrast, populations with an established resistance character would not present this problem.

We consider that the sample number is an important limiting factor when assessing insecticide resistance. In addition, stochastic variability sources within the studied population must be taken into account. The study developed by Amelotti et al. [43] showed that females within an age range can produce individuals with different susceptibility profiles. Due to that, they recommended increasing the sample number to at least 60 individuals with no less than 10 females and with different ages represented per population. This approach would increase the reliability of the obtained results, avoiding false negatives and reducing incorrect interpretation.

During our study domestic populations of T. infestans from the Tamachindi and Rancho Nuevo communities, both from the Gran Chaco of the Santa Cruz Department (non-Andean region), were also evaluated. These populations were less susceptible than the SRL with a $R_{50}$ of 4.21 and 5.04 respectively. They both had $93 \%$ mortality to the DD. In several communities of the same region Depickère et al. [14] reported reduced susceptibility to deltamethrin in domestic $T$. infestans. It is possible that lower levels of insecticide susceptibility play an important role in the reinfestation process of domestic dwellings. 
Population genetics studies performed by Quisberth et al. [44] have confirmed that the reinfestation of houses in these communities happens due to residual populations and not due to invasion of wild bugs.

However, the resistance levels registered for populations collected in communities from the Gran Chaco of the Santa Cruz Department (non-Andean region) both in our study and by Depickère et al. [14], are not as high as the levels we registered for the Villa Montes population ( $R R>129.12$ and $0 \%$ mortality to the DD). The latter, is considered as an Intermediate group, a result of the cross between Andean and non-Andean individuals [45]. Lardeux et al. [21] and Depickère et al. [14] emphasized that $T$. infestans populations from the Santa Cruz Department, where non-Andean populations occur, are more susceptible to deltamethrin. So Tarija populations (Intermediate), where high levels of resistance have been observed, also show low levels of mortality to the DD $(<20 \%)$ [14,19-21]. These observations are very important since they correspond to a border area between Argentina and Bolivia, where high resistance levels have been reported [18,20].

Our study has also evaluated different $T$. infestans domestic and wild morph populations from different regions in Bolivia, both from the Inter-Andean Valleys (Andean region) and Gran Chaco (non-Andean region). For each population we obtained different susceptibility profiles. Recent studies indicate that most wild populations of T. infestans of the Andean regions in Bolivia are susceptible to deltamethrin $[14,21,27]$. However, resistance to deltamethrin and fipronil has also been reported in some wild populations from the Julo Grande and Kirus Mayu (Potosí Department) and Mataral (Cochabamba Department) in Bolivia $[14,27]$. Thus, our data and the aforementioned reports, support the idea that populations of $T$. infestans from different geographic areas and morphs have different toxicological profiles [15,21,22,27].

Population genetics studies consider Bolivia as a center of origin and dispersion of $T$. infestans [8,45-48]. The existence of wild foci and different morphs of this species, added to its wide distribution in that country [8-10,49], suggest a high genetic variability of this species in Bolivia. Therefore, Dias \& Schofield [50] consider that the high genetic variability of $T$. infestans would explain why natural resistance and high levels of resistance to insecticides have developed in Bolivia.

Slope values have been used as indicators of population heterogeneity [27]. High slope values are related to low genetic variation, whereas populations in process of selection and thus showing genetic variation relate to less steep slopes (when compared to SRL slope) [51]. In this study 4 out of the 9 tested populations had values that suggest phenotypic variation. The three wild dark morph susceptible populations, and the domestic Villa Montes resistant population (Table 1).
The different toxicological profiles determined for domestic and wild populations of $T$. infestans could be the result of selective pressure from insecticide application plus the genetic variability of the highly structured populations present in this country [52-56]. Moreover, genetic studies through chromosomal markers performed by Panzera et al. [45] suggest that pyrethroid resistant populations from the Argentinean-Bolivian border are most likely the result of recent secondary contact between both chromosomal groups (Andean and non-Andean) suggesting a correlation between genomic variability and insecticide resistant populations.

The origin of resistance is unknown in wild Bolivian populations, because they have never had contact with insecticides and is probably due genetic variability. However, more genetic studies should be performed to characterize the resistance phenotype.

\section{Conclusion}

Wild and domestic $T$. infestans populations from the Inter-Andean Valleys (Andean region) and Gran Chaco (non-Andean region) from Bolivia, have different susceptibility profiles towards deltamethrin. Although most wild populations are susceptible, insecticide resistance was observed in one. The existence of wild foci and different morphs of $T$. infestans plus its wide distribution in Bolivia are indicative of genetic variability. This could explain the occurrence of resistance in wild populations and thus we suggest that more genetic studies are performed on these populations and the resistance phenotypes are tested under field conditions.

\section{Abbreviations \\ Ng: Nano grams; mg: Milligrams; a.i: Active ingredient; ${ }^{\circ} \mathrm{C}$ : Celsius degree; $\mu \mathrm{L}$ : Microliters; $\mathrm{RH}$ : Humidity relative.}

\section{Competing interests}

The authors declare that they have no competing interests.

\section{Authors' contributions}

All the authors have contributed substantially to this study. Conceived and designed the experiments: MBG, GCDP, LGD. Performed the experiments: MBG, ACLR. Analyzed the data: MBG, GCDP. Contributed material biologic: ALGO, MRC, FN. Wrote the paper: MBG, GCDP, LGD. All authors read and approved the final manuscript.

\section{Acknowledgements}

This study was supported by the Project No. 9871 FAPEMIG/FIOCRUZ/ CPQRR/DEMANDA UNIVERSAL; PEC-PG Capes/Brazil through granting of a doctoral scholarship of Marinely Bustamante Gomez.

We thank to the Escuela Técnica de Salud together with Roberto Rodriguez and Jorge Espinoza; IRD - Bolivia and to the National Chagas Desease

Control Program of Bolivia for assistance in the collection of Triatominae on the field; to Bayer S.A. Brazil for providing the insecticide used; Luis Martinez Villegas for the correction of English and especially to François Noireau (1955 - 2011) for incentivizing this research, making this article as a tribute to his memory.

\section{Author details}

1'Laboratório de Triatomíneos e Epidemiologia da Doença de Chagas, Centro de Pesquisas René Rachou - FIOCRUZ Minas, Belo Horizonte, Brazil. ${ }^{2}$ Instituto 
de Investigaciones Biomédicas - Facultad de Medicina, Universidad Mayor de San Simón, Cochabamba, Bolivia. ${ }^{3}$ CEADES Salud y Medio Ambiente, Cochabamba, Bolivia. Institute de Recherche pour le Developemente (IRD), La Paz, Bolivia.

Received: 9 June 2014 Accepted: 21 October 2014

Published online: 14 November 2014

\section{References}

1. World Health Organization: Control of Chagas disease, WHO Technical Report Series 811. Geneva: World Health Organization; 1991.

2. Dias PJC: Southern Cone Initiative for the elimination of domestic populations of Triatoma infestans and the interruption of transfusional Chagas disease. Historical aspects, present situation, and perspectives. Mem Inst Oswaldo Cruz 2007, 102(1):11-18.

3. Schofield CJ, Dias JCP: The Southern Cone Initiative against Chagas disease. Adv Parasitol 1999, 42:1-27.

4. Dias JCP: O controle da doença de Chagas no Brazil. In El Control de la Enfermedad de Chagas en los Países del Cono Sur de América. Historia de una Iniciativa Internacional. 1991/2001. Edited by Silveira AC. Uberaba: Faculdade de Medicina do Triângulo Mineiro; 2002:145-250.

5. Schofield CJ, Jannin J, Salvatella R: The future of Chagas disease control. Trends Parasitol 2006, 12:583-588

6. Gürtler RE: Sustaintability of vector control strategies in the Gran Chaco Region: current challenges and possible approaches. Mem Inst Oswaldo Cruz 2009, 104(1):52-59.

7. Germano MD, Picollo MI, Mougabure-Cueto GA: Microgeographical study of insecticide resistance in Triatoma infestans from Argentina. Acta Trop 2013, 28(3):561-565.

8. Waleckx E, Salas R, Huamán N, Buitrago R, Bosseno MF, Aliaga C, Barnabé C, Rodriguez R, Zoveda F, Monje M, Baune M, Quisberth S, Villena E, Kengne P, Noireau F, Brenière SF: New insights on the Chagas disease main vector Triatoma infestans (Reduviidae, Triatominae) brought by the genetic analysis of Bolivian sylvatic populations. Infect Genet Evol 2011, 11:1045-1057.

9. Waleckx E, Depickère S, Salas R, Aliaga C, Monje M, Calle H, Buitrago R, Noireau F, Brenière SF: New discoveries of sylvatic Triatoma infestans (Hemiptera: Reduviidae) throughout the Bolivian Chaco. Am J Trop Med Hyg 2012, 86:455-458.

10. Noireau F: Wild Triatoma infestans, a potential threat that needs to be monitored. I Mem inst Oswaldo Cruz 2009, 104:60-64.

11. Ceballos LA, Piccinali RV, Berkunsky I, Kitron U, Gürtler RE: First finding of melanic sylvatic Triatoma infestans (Hemiptera: Reduviidae) colonies in the Argentine Chaco. J Med Entomol 2009, 46:1195-1202.

12. Bacigalupo A, Torres-Perez F, Segovia V, Garcia A, Correa JP, Moreno L, Arroyo P, Cattan PE: Sylvatic foci of the Chagas disease vector Triatoma infestans in Chile: description of a new focus and challenges for control programs. Mem Inst Oswaldo Cruz 2010, 105:633-641.

13. Rolón M, Vega MC, Román F, Gómez A, Rojas de Arias A: First report of colonies of sylvatic Triatoma infestans(Hemiptera: Reduviidae) in the Paraguayan Chaco, using a trained dog. PLoS Negl Trop Dis 2011, 5:e1026

14. Depickère S, Buitrago R, Siñani E, Baune M, Monje M, Lopez R, Waleckx E, Chavez T, Brenière SF: Susceptibility and resistance to deltamethrin of wild and domestic populations of Triatoma infestans (Reduviidae: Triatominae) in Bolivia: new discoveries. Mem Inst Oswaldo Cruz 2012, 107(8):1042-1047.

15. Cecere MC, Vazquez-Prokopec GM, Gurtler RE, Kitron U: Spatio-temporal analysis of reinfestation by Triatoma infestans (Hemiptera: Reduviidae) following insecticides praying in a rural community in north western Argentina. Am J Trop Med Hyg 2004, 71:803-810

16. Marcet PL, Mora MS, Cutrera AP, Jones L, Gurtler RE, Kitron U, Dotson EM: Genetic structure of Triatoma infestans populations in rural communities of Santiago del Estero, northern Argentina. Infect Gene Evol 2008, 8:835-846.

17. Gürtler RE, Kitron U, Cecere MC, Segura EL, Cohen JE: Sustainable vector control and management of Chagas disease in the Gran Chaco, Argentina. Proc Natl Acad Sci 2007, 104:16194-16199.

18. Picollo MI, Vassena CV, Santo-Orihuela P, Barrios S, Zaidemberg M, Zerba EN: High resistance to pyrethroid insecticides associated with ineffective field treatments in Triatoma infestans (Hemiptera: Reduviidae) from Northern Argentina. J Med Entomol 2005, 42:637-642.
19. Santo-Orihuela PL, Vassena CV, Zerba EN, Picollo Ml: Relative contribution of monooxygenase and esterase to pyrethroid resistance in Triatoma infestans (Hemiptera: Reduviidae) from Argentina and Bolivia. J Med Entomol 2008, 45:298-306.

20. Germano MD, Roca-Acevedo G, Mougabure-Cueto GA, Toloza AC, Vassena CV, Picollo Ml: New findings of insecticide resistance in Triatoma infestans (Heteroptera: Reduviidae) from the Gran Chaco. J Med Entomol 2010, 47:1077-1081.

21. Lardeux F, Depickere S, Duchon S, Chavez T: Insecticide resistance of Triatoma infestans (Hemiptera, Reduviidae) vector of Chagas disease in Bolivia. Trop Med Int Health 2010, 15:1037-1048.

22. Vassena CV, Picollo MI, Santo-Orihuela P, Zerba EN: In Triatominos de Bolivia y la Enfermedad de Chagas. Edited by Cortez MR. Ministerio de Salud y Deportes de Bolivia - Programa Nacional de Chagas; 2007:229-255.

23. Alarico AG, Romero N, Hernández L, Catalá S, Gorla D: Residual effect of a micro-encapsulated formulation of organophosphates and piriproxifen on the mortality of deltamethrin resistant Triatoma infestans populations in rural houses of the Bolivian Chaco region. Mem Inst Oswaldo Cruz 2010, 105:752-756.

24. Pedrini N, Mijailovsky SJ, Girotti JR, Stariolo R, Cardozo RM, Gentile A, Juárez MP: Control of pyrethroid-resistant Chagas disease vectors with ento-mopathogenic fungi. PLoS Negl Trop 2009, 3:e434.

25. Fabro J, Sterkel M, Capriotti N, Mougabure-Cueto G, Germano M, Rivera-Pomar $\mathrm{R}$, Ons S: Identification of a point mutation associated with pyrethroid resistance in the paratype sodium channel of Triatoma infestans, a vector of Chagas disease. Infect Genet Evol 2012, 12:487-491.

26. Germano MD, Santo-Orihuela P, Roca-Acevedo G, Toloza AC, Vassena C, Picollo Ml, Mougabure-Cueto G: Scientific evidence of three different insecticide-resistant profiles in Triatoma infestans (Hemiptera: Reduviidae) populations from Argentina and Bolivia. J Med Entomol 2012, 49:1355-1360

27. Roca-Acevedo G, Germano M, Santo-Orihuela P, Mougabure Cueto G, Cortez MR, Noireau F, Picollo MI, Vassena C: Susceptibility of wild Triatoma infestans from Andean Valleys of Bolivia to Deltamethrin and Fipronil. $J$ Med Entomol 2011, 48:828-835.

28. Noireau F, Rojas Cortéz MG, Monteiro FA, Jansen AM, Torrico F: Can wild Triatoma infestans foci in Bolivia jeopardize Chagas disease control efforts? Trends Parasitol 2005, 21:7-10.

29. Ceballos LA, Piccinali RV, Marcet PL, Vazques-Prokopec GM, Cardinal MV, Schachter-Broide J, Dujardin JP, Dotson EM, Kitrom U, Gürtler RE: Hidden sylvatic foci of the main vector of Chagas disease Triatoma infestans: threats to the vector elimination campaign? PLOS Negl Trop Dis 2011, 5(10):1365

30. Noireau F, Flores R, Vargas F: Trapping sylvatic Triatominae (Reduviidae) in 210 hollow trees. Trans R Soc Trop Med Hyg 1999, 93:13-14.

31. Noireau F, Abad-Franch F, Valente SAS, Dias-Lima A, Lopes CM, Cunha V Valente VC, Palomeque FS, de Carvalho-Pinto CJ, Sherlock I, Aguilar M, Steindel M, Grisard EC, Jurberg J: Trapping Triatominae in silvatic habitats. Mem Inst Oswaldo Cruz 2002, 97:61-63.

32. Noireau F, Flores R, Gutierrez T, Dujardin JP: Detection of sylvatic dark morphs of Triatoma infestansin the Bolivian Chaco. Mem Inst Oswaldo Cruz 1997, 92:583-584

33. Cortez MR, Emperaire L, Piccinali RV, Gurtler RE, Torrico F, Jansen AM, Noireau F: Sylvatic Triatoma infestans (Reduviidae, Triatominae) in the Andean valleys of Bolivia. Acta Trop 2007, 102:47-54.

34. Panzera F, Dujardin JP, Nicolini P, Caraccio MN, Rose V, Tellez T, Bermudez $\mathrm{H}$, Bargues MD, Mas-Coma S, O'Connor JE, Perez R: Genomic changes of Chagas disease vector, South America. Emerg Infect Dis 2004, 10:438-446.

35. Lent H, Wygodzinsky P: Revision of the Triatominae (Hemiptera, Reduviidae), and their significance as vectors of Chagas' disease. Bull Amer Mus Nat Hist 1979:163.

36. Picollo Ml, Wood E, Zerba E, Licastro SA, Ruveda MA: Métodos de laboratorio para medir la actividad de insecticidas en Triatoma infestans. Acta Bioquim Clin Latinoam 1976, 10:67-71.

37. World Health Organization: Protocolo de evaluación de efecto insecticida sobre triatomineos. Acta Toxicol Argentina 1994, 2:29-32.

38. Pessoa GCD: Monitoramento da Suscetibilidade ao Piretróide Deltametrina em Populações de Triatoma sórdida Stål, 1859 (Hemiptera: Reduviidae). In Masters thesis. Centro de Pesquisa René Rachou FIOCRUZ/MG Pós-graduação em Ciências da Saúde. Área de concentração: Doenças Infecciosas e Parasitárias: 2008:43-45. 
39. World Health Organization: Guidelines for testing mosquito adulticides for indoor residual spraying and treatment of mosquito nets. WHO/CDS/ NTD/WHOPES/GCDPP/ 2006, 3:60.

40. Raymond M, Prato G, Ratsira D: PROBIT Analysis of Mortality Assays Displaying Quantal Response, Version 3.3. St. Georges d'Orques, France: Praxème Sarl; 1993.

41. Organización Panamericana de Salud: Il Reunión Técnica Latinoamericana de Monitoreo de Resistencia a Insecticidas en Triatomineos Vectores de Chagas Panamá. 11 al 13 de Abril 2005.

42. Picollo MI: Métodos de Detección y Monitoreo de Resistencia en Triatominos. Acta Toxicol Argent 1994, 2(1-2):29-58.

43. Amelotti I, Romero N, Catalá SS, Gorla DE: Variability of the Susceptibility to Deltamethrin in Triatoma infestans: the Female Factor. J Med Entomol 2011, 48(6):1167-1173.

44. Quisberth S, Waleckx E, Monje M, Chang B, Noireau F, Brenière SF: "Andean" and "non-Andean" ITS-2 and mtCytB haplotypes of Triatoma infestans are observed in the Gran Chaco (Bolivia): population genetics and the origin of reinfestation. Infect Genet Evol 2011, 11:1006-1014.

45. Panzera F, Ferreiro MJ, Pita S, Calleros L, Pérez R, Basmadjián Y, Guevara Y, Brenière SF, Panzera $Y$ : Evolutionary and dispersal history of Triatoma infestans, main vector of Chagas disease, by chromosomal markers. Infect Genet Evol 2014, 27:105-113.

46. Bargues MD, Klisiowicz DR, Panzera F, Noireau F, Marcilla A, Perez R, Rojas MG, O'Connor JE, Gonzalez-Candelas F, Galvão C, Jurberg J, Carcavallo RU, Dujardin JP, Mas-Coma S: Origin and phylogeography of the Chagas disease main vector Triatoma infestans based on nuclear rDNA sequences and genome size. PLoS Negl Trop Dis 2006, 6:46-62.

47. Cortez MR, Monteiro FA, Noireau F: New insights on the spread of Triatoma infestans from Bolivia implications for Chagas disease emergence in the southern cone. Infect Genet Evol 2010, 10:350-353.

48. Torres-Perez F, Acuna-Retamar M, Cook JA, Bacigalupo A, Garcia A, Cattan PE: Statistical phylogeography of Chagas disease vector Triatoma infestans: testing biogeographic hypotheses of dispersal. Infect Genet Evol 2011, 11:167-174.

49. Buitrago R, Waleckx E, Bosseno MF, Zoveda F, Vidaurre P, Salas R, Mamani E, Noireau F, Brenière SF: First report of widespread wild populations of Triatoma infestans (Reduviidae, Triatominae) in the valleys of La Paz, Bolivia. Am J Trop Med Hyg 2010, 82:574-579.

50. Dias JP, Schofield CJ: Introducción. In Triatominos de Bolivia y la enfermedad de Chagas. Edited by Cortez MR. Bolivia: Ministerio de Salud y Deportes de Bolivia - Programa Nacional de Chagas; 2007:229-255.

51. Chilcutt CF, Tabashnik BE: Evolution of pesticide resistance and slope of the concentration-mortality line: are they related? J. Econ Entomol 1995, 88:11-20.

52. de Rosas ARP, Segura EL, García BA: Microsatellite analysis of genetic structure in natural Triatoma infestans (Hemiptera: Reduviidae) populations from Argentina: its implication in assessing the effectiveness of Chagas' disease vector control programmes. Mol Ecol 2007, 16:1401-1412.

53. de Rosas ARP, Segura EL, Fichera L, García BA: Macrogeographic and microgeographic genetic structure of the Chagas' disease vector Triatoma infestans (Hemiptera:Reduviidae) from Catamarca, Argentina. Genetica 2008, 133:247-260.

54. Abrahan L, Hernández L, Gorla D, Catalá S: Phenotypic Diversity of Triatoma infestans at the microgeographic level in the Gran Chaco of Argentina and the Andean valleys of Bolivia. J Med Entomol 2008, 45:660-666.

55. Pizarro JC, Gilligan LM, Stevens L: Microsatellites reveal a high population structure in Triatoma infestans from Chuquisaca. Bolivia. PLoS Negl Trop Dis 2008, 2(3):e202. doi:10.1371/journal.pntd.0000202.

56. Segura EL, Torres AG, Fusco O, Garcia A: Mitochondrial 16S DNA variation in populations of Triatoma infestans from Argentina. Med Vet Entomol 2009, 23:34-40.

doi:10.1186/s13071-014-0497-3

Cite this article as: Gomez et al:: Susceptibility to deltamethrin of wild and domestic populations of Triatoma infestans of the Gran Chaco and the Inter-Andean Valleys of Bolivia. Parasites \& Vectors 2014 7:497.

\section{Submit your next manuscript to BioMed Central and take full advantage of:}

- Convenient online submission

- Thorough peer review

- No space constraints or color figure charges

- Immediate publication on acceptance

- Inclusion in PubMed, CAS, Scopus and Google Scholar

- Research which is freely available for redistribution

Submit your manuscript at www.biomedcentral.com/submit
Ciomed Central 